\title{
Design a Mobile Learning Application to Learn Hijaiyah Letters Based on Android
}

\author{
Suheri \\ Faculty of Science and Technology, University of Development Panca Budi, Medan, Indonesia
}

\begin{abstract}
Mobile learning is a learning process that utilizes technological developments through electronic devices in the form of smartphones or mobile phones. Currently learning hijaiyah is still widely done by meeting directly with the teaching staff, through Iqra or other print media. With this is considered less effective and ineffective and causes boredom for children. Therefore, an efficient, effective and interactive hijaiyah letter learning media is needed that can improve children's reasoning power to learn anywhere and anytime. The application will be designed with a system design tool that is UML (Unified Modeling language) that is easy to describe so that it can help in the compounding of the system. The application will be implemented on android-based mobile devices.
\end{abstract}

Keywords: Android, Hijaiyah, M-Learning, UML.

\section{INTRODUCTION}

The development of mobile device technology today allows the need for information to be met. With increasingly rich features and is the right solution for the need to get information. One example of telecommunications tools that are experiencing significant development is a mobile telecommunications tool that uses the Android operating system. Through Android developers are able to use it to build an electronic mobile learning system called mobile learning. The existence of applications on mobile devices can overcome problems for the presentation of information at this time including information about hijaiyah letters and how to read it so far to get the information through teachers, religious figures, books, brochures and the like that are less practical, take special time, place, and cost so that it becomes a problem and it can be facilitated by the existence of a more interactive mobile learning application, It can be accessed anywhere and anytime.

Android-based mobile learning applications have been widely developed including Design Iqra Learning Application For Early Childhood Based on Android (Busran and Nindya Debby Yunanda, 2015). From the journal that has been published it can be known that learning application programs can run on the Android operating system which greatly helps the learning process and improves understanding in interesting ways.

With the development of information technology and the manifestation of the positive impact of information technology development, the author tries to facilitate children in learning hijaiyah letters and how to read them that are interactive and effective.

\section{LITERATURE REVIEW \\ MOBILE LEARNING}

Mobile learning can be done with distance learning, making it easier for learners to learn. In addition, with mobile learning-based E-books this can help visualize abstract material so as to help the understanding of learners (Dwi, et al. 2018).

The learning media developed contains basic materials while while video on knowledge that is abstract concepts, so that students can understand the material discussed. 
Mobile learning is learning that uses mobile devices such as PDAs, mobile phones, laptops and other information technology equipment for learning (Ariesto Hadi Sutopo, 2012: 175). The advantage of m-learning is that learning can access materials, guides and applications related to learning that can be accessed anytime and anywhere.

The benefits of learning media that can make learning become more attractive to learners so that it can foster learning motivation. Teaching materials can also become clearer so that they are easily understood by learners. M-Learning is part of electronic learning (e-learning) so itself is also part of distance learning (d-learning). Based on some opinions from experts, it can be concluded that mobile learning is a learning model that utilizes mobile devices to access it. Mobile learning-based e-books developed by developers are included in learning that utilizes mobile as an access device using students' android smartphones.

There are five advantages of Mobile learning among others, namely users can access learning content can be done from anywhere including quizzes, journals, games and others, learning can be done at any time in real time, the use of books is replaced with RAM that can organize and connect learning, learning is designed to be used on mobile devices and learning combined with games will be fun (Dwi, et al. 2018)

- Content can be accessed at any time

- Content can be accessed anywhere

- Support distance learning

- Can improve student-centered learning

- Great for short training or just a content review.

- Mobile learning can be used more effectively for learners with different levels of ability.

- Provide support to students with different levels of learning and personalized learning.

- Can improve interaction between students, learners, and instructors
- Reduce barriers in terms of culture and communication between lecturers and students by using communication channels that students like.

\section{ANDROID}

Android is a Linux-based operating system used for mobile phones such as smartphones and tablet computers (PDAs) (Yosef Murya, 2014).

Android is an operating system for Linux-based mobile devices that includes operating systems, middleware and applications (Ichwan). M, et al. 2013). Android provides an open platform for developers to create their own apps that will be used to help with activities in various fields, so that it can be used by everyone who wants to use it on their devices.

Android is a Linux-based operating system designed for touchscreen mobile devices such as smartphones and tablet computers. Android was originally developed by Android, Inc. with the financial backing of Google, which bought it in 2005. (Kusniati, Dkk.2016).

\section{JAVA}

Java is a multi-platform and multidevice programming language. Java can be run on several different computer platforms and operating systems. Java-based applications are collected into pseudecode and can be run with JVM (Java VirtualMachine). The functionality of java can run on different operating system platforms due to its common and nonspecific nature. Java is also an OOP (Object Oriented Programming) programming language. Java has a complete library. The library here is a collection of programs included in Java. This will make programming easier (Desmira, 2015).

\section{ANDROID STUDIO}

Android studio is an Integrated Development Environment (IDE) integrated software development environment for Android app development, based on Intellij IDEA. In addition to being an Intellij code 
editor and a useful developer tool, Android Studio also offers many features to increase productivity when creating Android apps (Herlinah, 2019).

Android studio itself was developed based on IntelliJ IDEA which is similar to Eclipse accompanied by ADT plugin (Android Development Tools). Android Studio has the features:

- Projects based on Gradle Build

- Refactory and rapid bug fixes

- A new tool called "Lint" is expected to monitor the speed, usability, and compatibility of applications quickly.

- Supports Proguard And App-signing for security.

- Having an android app GUI is easier

- Powered by Google Cloud Platform for each application developed.

\section{SQLITE}

SQLite is an opensource database grown on Android. The support provided is the same as the standard RDMS and also supports SQL syntax language (Computer Vehicle, 2015: 120). SQLite is an ACIDcompliant relational database management system that has a relatively small library size. This software is written in $\mathrm{C}$ language.

\section{HIJIAYAH LETTERS}

According to Ath. Thabari (1999:27) explains that the letter hijaiyah is one of the typical types of language featured in the Qur'an. Al -Qu'ran is indeed arranged using hijaiyah letters with different makhraj while hinting that the Qur'an is derived in Arabic.

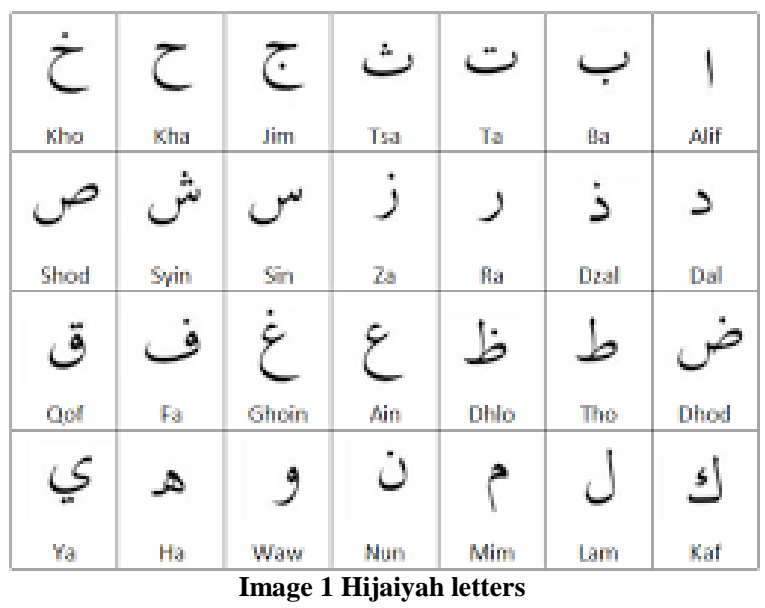

Otory Surasman (2002:52) suggests that "the letter hijaiyah is the basic key to being able to read the Qur'an. The letter hijaiyah is used as a spelling to write a word or sentence in the Qur'an.

\section{METHODS}

The stages of research that will be carried out in the writing of this research are as follows:

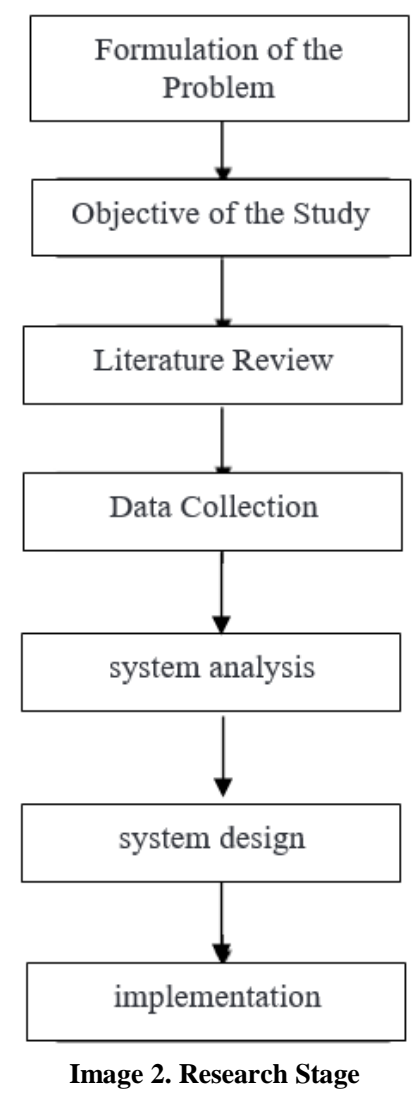

The research methodology that will be carried out in the research is as follows:

\section{a. Study literary}

At this stage, data collection is required by studying and selecting books, journals, papers and several sites related to research.

\section{b. Needs Analysis}

This analysis is done to find out the scope of the application of hijaiyah letter learning to be built.

\section{c. Application Planning}

This stage is the stage of designing the flow of the learning application and also 
creating the interface design of the application.

\section{d. Program Testing}

At this stage, testing of the application has been made.

\section{RESEARCH DESIGN}

The designs used in this study are Use Case Diagram, Sequence Diagram, Activity Diagram, Database, and output and input design.

The design of the Use Case Diagram for users of this Android-based hijaiyah letter learning application can be seen in the following image:

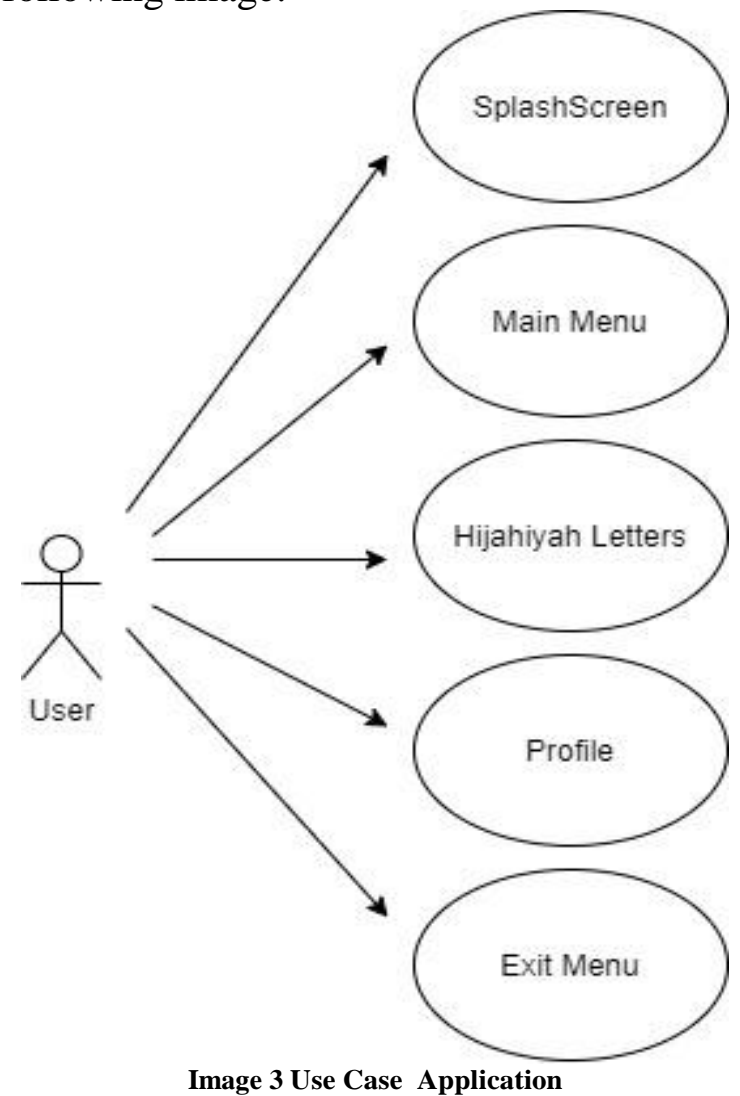

Sequence Diagram design of this Android-based hijaiyah letter learning application can be seen in the following image:

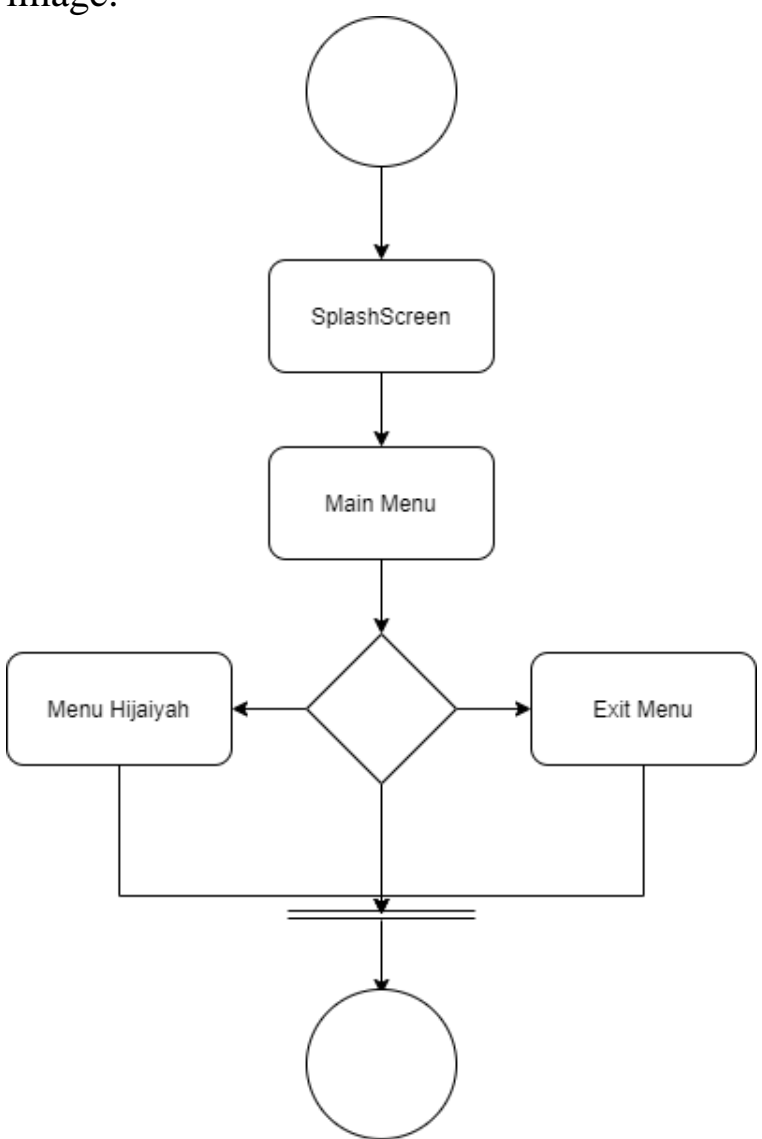

Image 4 Activity Diagram Application Learning Hijaiyah Letters

Here is an overview of the interface of the hijaiyah-based android-based martial arts application that will be built. In the following image will be designed splashscreen interface that will be displayed if the user accesses the application. Splashscreen appears on the first view of the accessed app.

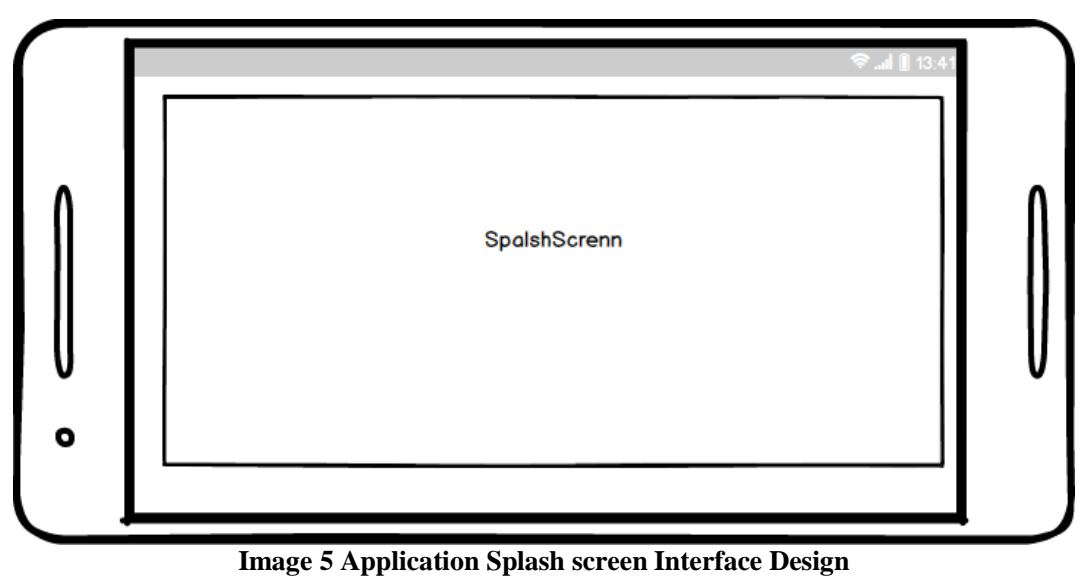


Here is a display of the interface of the main menu design of the application to be built that will be displayed as an interface to the user when accessing the application and utilizing the application to learn hijaiyah letters.

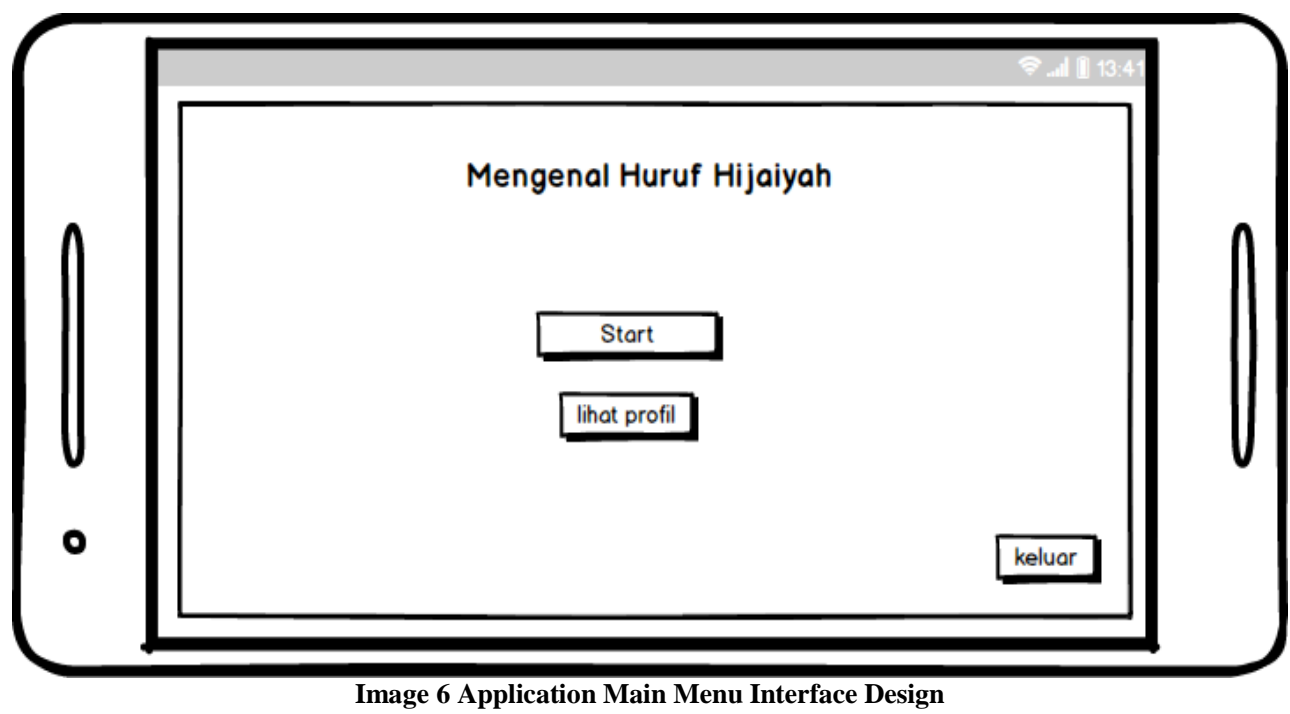

In the design interface of the image below describes the design that will be displayed if the user is expected to access the hiijaiyah letter menu from the main menu that will display hijaiyah letters, spelling, readings and sounds of hijaiyah readings that will be studied by the user.

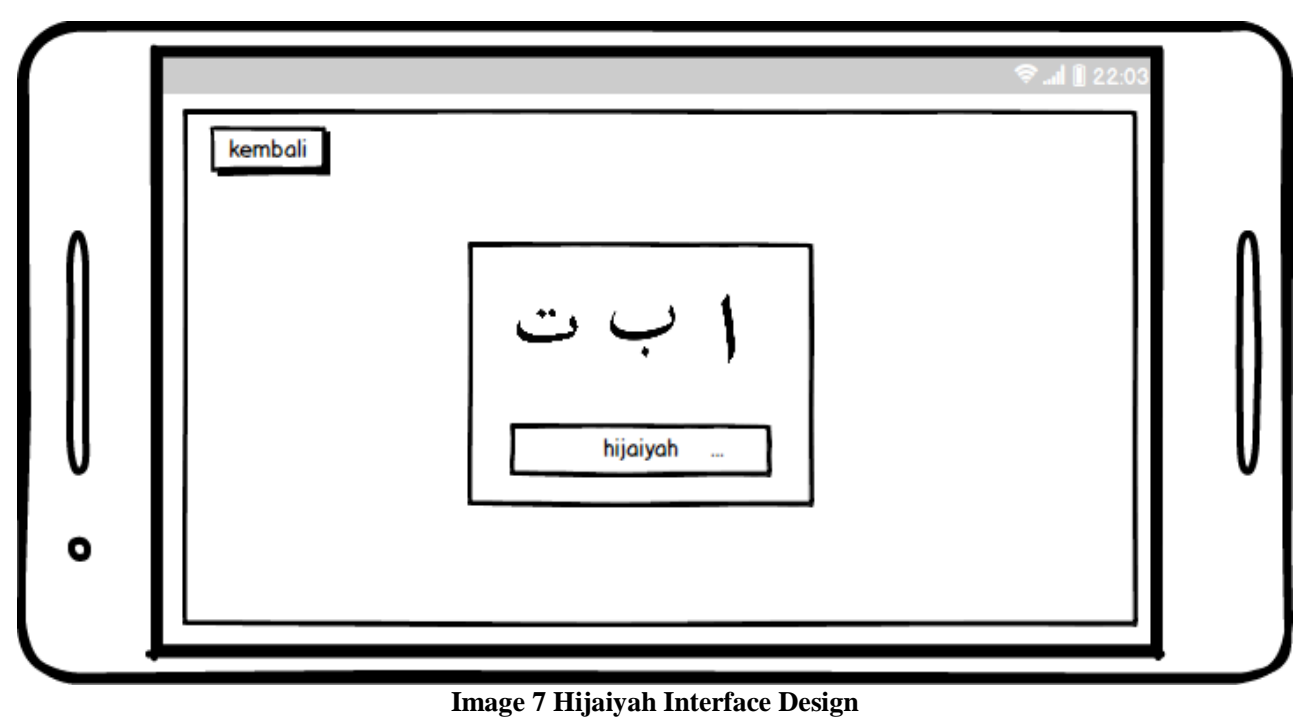

\section{RESULT AND DISCUSSION}

System implementation is the result of execution of a designed application or program. The results of this study will be explained the implementation of the application on Android-based mobile devices and how the current appearance of the application is operated on an Androidbased mobile device.

\section{MAIN MENU INTERFACE VIEW}

The main menu view of the application will present the contents of the information that will be displayed on the application that is accessed by the user. In figure 4.6 can be seen the main menu view of the application as follows: 


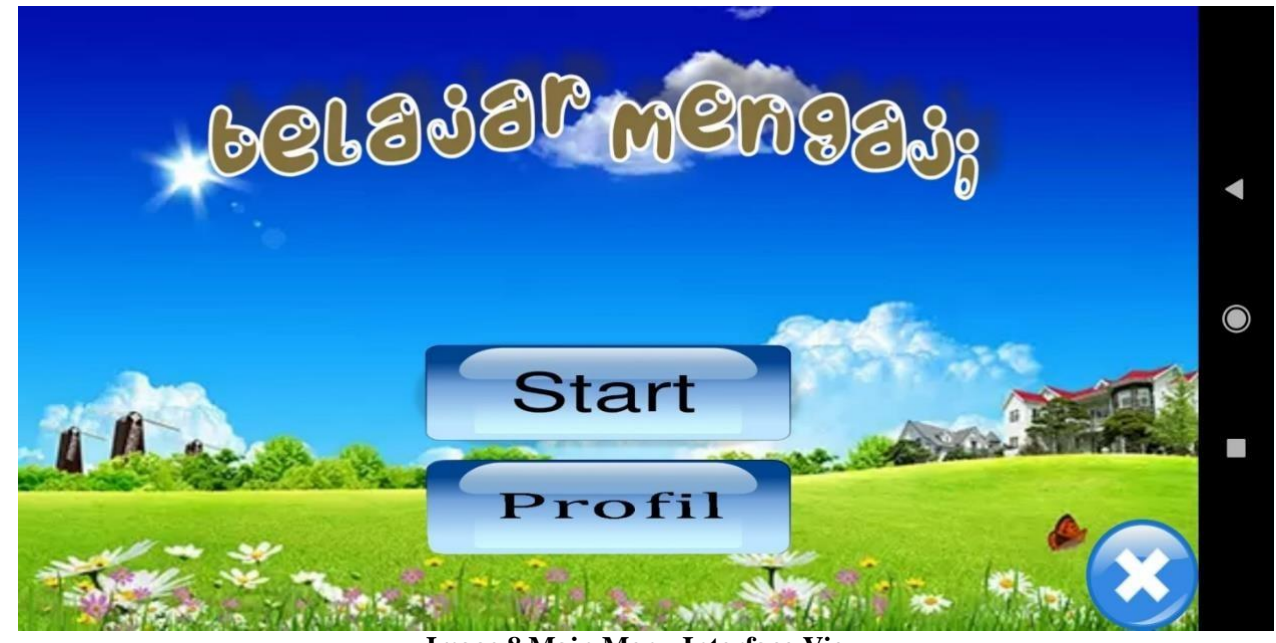

Image 8 Main Menu Interface View

\section{Start Menu Listview Interface View}

When the user selects the start menu, it will display a listview view from the start menu. In figure 9 can be seen the appearance of the start menu listview interface in the Mobile Learning Application hijaiyah letter recognition as follows:

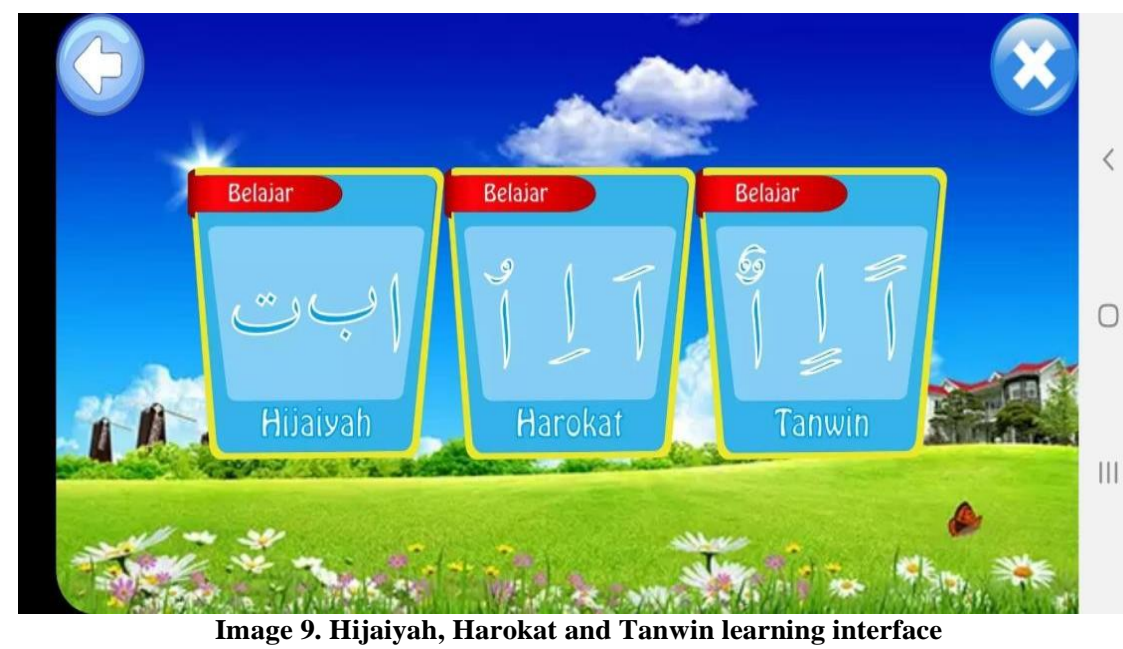

In figure 9 above is the design of the listview menu start to start the introduction and learn the letters hijaiyah, Harokat and Tanwin. In figure 4.8 the following can be seen the contents of the interface of one of the listviews of the hijaiyah learning menu displayed on the Application:

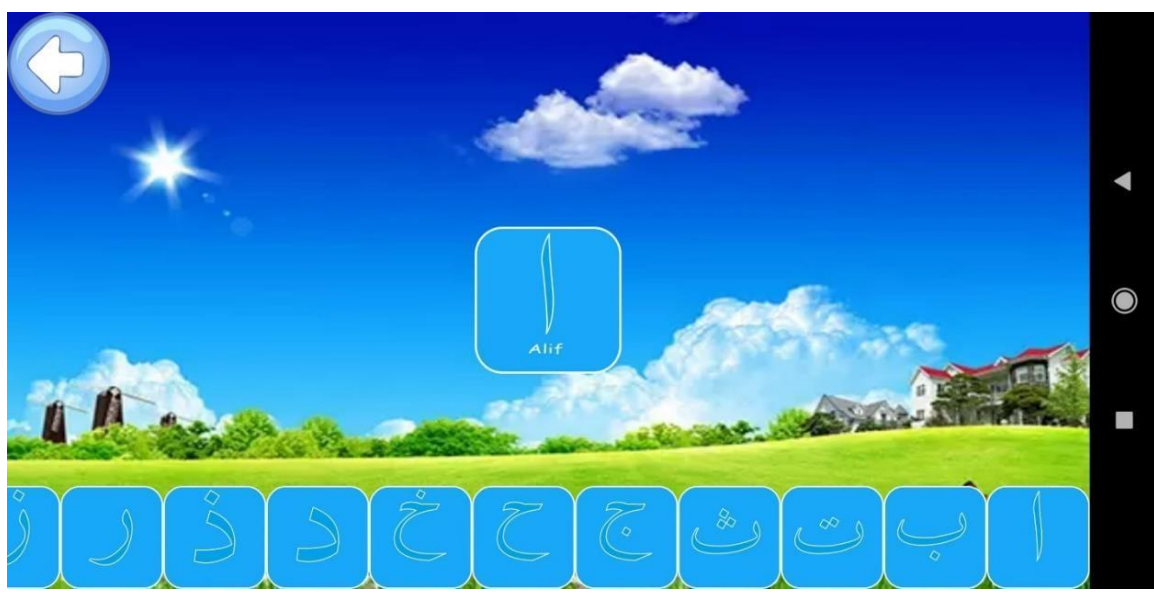

Image 10. Listview Content Interface display of hijaiyah letters 
In figure 10 above can be seen the contents of the display of hijaiyah letters displayed so that when the user chooses one of the letters, the application will display the letter accompanied by audio or reading sounds from the hijaiyah letter. The interface of the sound will be displayed in the form of pop ups so that it is more interactive.

\section{CONCLUSION}

Based on the results of the Hijaiyah Letter Recognition Mobile Learning Design it can be concluded that: 1) With the mobile learning application operated on Android mobile devices can facilitate the process of learning about hijaiyah letters that can be done anytime and anywhere that is more interactive. 2) Application of uml object modeling object oriented system method (Unified Modeling Language) can provide a very complex modeling by providing a description of system flow and logic in the system designed, namely Mobile Learning Application Hijaiyah Letter Recognition.

\section{Acknowledgement: None}

\section{Conflict of Interest: None}

\section{Source of Funding: None}

\section{REFERENCES}

1. Busran and Yunanda, N. D. (2015). "Design Iqra Learning App For Android-
Based Early Childhood" Journal momentum. Vol. 17 No. 1. 78-83.

2. Dwi Z, et al. (2018) E-Book based on mobile learning. JKTP Volume 1, Number 2,. 109- 114

3. Sutopo, Ariesto Hadi. (2012). Information technology and communication in education. Yogyakarta: Graha Ilmu.

4. Ade Hendini, 2016. "UML Modeling Information System Monitoring Sales and Stock of Goods (Case Study: Distro Zhezha Pontianak)". Journal of Students of Informatics Management Study Program AMIK BSI Pontianak

5. Ichwan, M. et al. (2013). "Construction of Prototype Of Electrical Equipment Control System on Android Platform" Informatics Journal. Vol. 4. No. 1. 13-25.

6. Murya, Y. (2014). "Android Blackbox programming". Jasakom

7. Nazruddin Safaat H. (2015). "Androidbased apps". Bandung: Informatics bandung.

8. Rosa and M. Salahuddin. (2013). Software Engineering: Structured and Object-Oriented. Bandung: Informatics.

9. Desmira, (2015). Design of android-based Islamic education introduction application for early childhood education in information system journal vol 2.2015

10. Herlinah, (2019). "Android-Based PreMarriage Mobile Learning Application Development Using Unity 3D V5 Technology". Journal of Informatics Science and Technology Volume 3 Number 2 October 2018.

How to cite this article: Suheri. Design a mobile learning application to learn hijaiyah letters based on android. International Journal of Research and Review. 2021; 8(10): 218-224. DOI: https://doi.org/10.52403/ijrr.20211028 